\title{
Arabica coffee and cedar tree: integrating biotic and abiotic drivers
}

Arborização de cafezais arábica com cedro: integração de fatores bióticos e abióticos

Luanna Fernandes Pereira ${ }^{1}$ (D), Sylvana Naomi Matsumoto ${ }^{2}$ (D), Ueliton Soares de Oliveira ${ }^{1}$ (D), Anselmo Eloy Silveira Viana ${ }^{2}$ (), Ednilson Carvalho Teixeira ${ }^{2}$ (1)

\begin{abstract}
A B S T R A C T
Agroforestry systems are important forms of sustainable farming, providing several ecosystem services. However, characterization and management of factors such as thermal and light heterogeneity, as well as interactions between trees and coffee plants, are determinants for achieving the desired sustainability. This study aimed to verify whether different distances between Coffea arabica L. and Australian red cedar can change soil and microclimate characteristics and how they alter morphological and physiological attributes of coffee plants over the rainy season and a prolonged drought period (veranico) in Summer. The trial was carried out in the municipality of Barra do Choça, in an area with Australian red cedar trees (Toona ciliata M. Roem), distributed in two hedges, spaced $19.8 \times 3 \mathrm{~m}$ apart, in a northeastsouthwest direction, and coffee plants var. Catucaí Vermelho $(3.3 \times$ $0.5 \mathrm{~m}$ ). Treatments were defined by the distance between the coffee plants and the first row of the Australian red cedar hedge $(3.3 \mathrm{~m}$, T1; 6.6 m, T2; 9.9 m, T3; 13.2 m, T4; 16.4 m, T5). Morphology and physiology of coffee plants, soil temperature, incident light on coffee plants, and the allelopathic potential of Australian red cedar leaf extracts were assessed in the wet and dry season of the 2016-2017 Summer. Temperatures fluctuated less in experimental units close to the hedge. The reduced growth of coffee plants close to the hedges was related to self-shading associated with light restriction by the trees. The experiment showed the allelopathic potential of Australian red cedar leaves.
\end{abstract}

Keywords: agroforestry system; Coffea arabica; Toona ciliata M. Roem; allelopathy; shading.

\begin{abstract}
RE S U M 0
Os sistemas agroflorestais são importantes formas de cultivo sustentável, gerando diversos serviços ecossistêmicos. Entretanto, a caracterização e o manejo de fatores como a heterogeneidade térmica e de radiação luminosa, e a interação entre componente arbóreo e os cafeeiros são determinantes para atingir a sustentabilidade almejada. O objetivo deste trabalho foi verificar se diferentes distâncias entre Coffea arabica L. e cedro australiano podem alterar as características do solo e do microclima e como isso altera os atributos morfológicos e fisiológicos das plantas de café durante a estação chuvosa e um período prolongado de seca (veranico) de verão. $O$ ensaio foi conduzido no município de Barra do Choça, em área composta por árvores de cedro australiano (Toona ciliatta $\mathrm{M}$. Roem) dispostas em dois renques subsequentes, com espaçamento de $19,8 \times 3 \mathrm{~m}$, sentido Nordeste-Sudoeste, e cafeeiros arábica var. Catucaí Vermelho $(3,3 \times$ $0,5 \mathrm{~m})$. Os tratamentos foram definidos pela distância dos cafeeiros em relação à primeira linha do renque de cedro $(3,3 \mathrm{~m}, \mathrm{T1} ; 6,6 \mathrm{~m}, \mathrm{T2}$; 9,9 m, T3; 13,2m, T4; e 16,5 m, T5). A morfofisiologia dos cafeeiros, a temperatura do solo, a radiação luminosa incidente nos cafeeiros de cada parcela e o potencial alelopático dos extratos de folhas do cedro australiano foram avaliados na estação úmida e seca do verão 2016/2017. Menor amplitude da variação térmica foi verificada nas áreas próximas ao renque. A redução do vigor de crescimento dos cafeeiros próximos aos renques de cedro foi relacionada ao autossombreamento associado à restrição de luz pelas árvores. Observou-se o potencial alelopático das folhas de cedro australiano.
\end{abstract}

Palavras-chave: sistema agroflorestal; Coffea arabica; Toona ciliatta M. Roem.; alelopatia; sombreamento.

\footnotetext{
${ }^{1}$ Universidade Federal de Viçosa - Viçosa (MG), Brazil.

${ }^{2}$ Universidade Estadual do Sudoeste da Bahia - Vitória da Conquista (BA), Brazil.

Correspondence address: Sylvana Naomi Matsumoto - Avenida Fortaleza, 39 - Candeias - CEP 45029-090 - Vitória da Conquista (BA), Brasil E-mail: snaomi@uesb.edu.br.

Conflicts of interest: the authors declare that there are no conflicts of interest.
}

Funding: Coordination for the Improvement of Higher Education Personnel (CAPES).

Received on: 04/17/2020. Accepted on: 10/30/2020.

https://doi.org/10.5327/Z21769478763

This is an open access article distributed under the terms of the Creative Commons license. 


\section{Introduction}

Agroforestry systems are important forms of sustainable land use, with activities that may produce substantial environmental benefits, such as reducing the risk of extreme temperatures (Moreira et al., 2018; Coltri et al., 2019), promoting carbon sequestration and biomass accumulation (Meireles et al., 2019), nutrient cycling by means of a higher litter deposition (Galetti et al., 2018), and improving water use efficiency (Moreira et al., 2018; Padovan et al., 2018).

Sunlight availability is generally studied by assessing the intensity of incident radiation, using shade net houses as an empirical basis (Dias et al., 2017; Bote et al., 2018; Ribeiro et al., 2019). Under this artificial environment, light distribution and intensity are predominately homogeneous, much different from what is observed in field conditions. A tree-based system is characterized by uneven sunlight exposure and fluctuating temperatures throughout the day when compared to crops grown in full sun (Alves et al., 2016; Coltri et al., 2019), and this difference is more pronounced when trees are planted in hedges. With this type of tree arrangement, shading is tied to the positioning of the hedges in relation to the solar path as the Earth rotates and orbits the Sun. The hedge orientation determines the different shade lengths over the coffee field, and monitoring the seasons and daytime weather changes is of utmost importance (Moreira et al., 2018).

There is a dynamic interaction between the incidence of light and canopy trees throughout the seasons, conditioning plant growth and microclimatic conditions arranged in an agroforestry system (Schwerz et al., 2020). Tree lines planted in an east-west direction promoted self-shading with different intensities over the seasons (da Silva Neto et al., 2019).

A

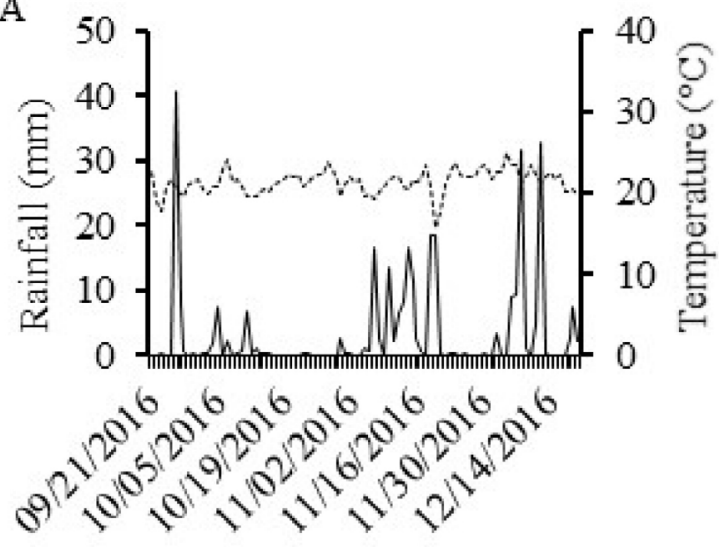

When dealing with the tree component in agroforestry systems, the main focus has been light interception; however, other factors, such as allelopathy, have been pushed into the background when composing agroforestry systems. The Australian red cedar, Toona ciliata M. Roem, has been used as a shade tree in coffee fields due to its high-quality wood (Oliveira et al., 2019), much appreciated for carpentry, decoration, and making musical instruments (Bhardwaj et al., 2018). This species is easily adaptable to different soils and climates (Divakar, 2017) and has low susceptibility to insects, such as Hypsipyla grandella Zeller (Oliveira et al., 2019).

This study aimed to verify whether different distances between Coffea arabica L. and Australian red cedar can change soil and microclimate characteristics and how they alter morphological and physiological attributes of coffee plants over the rainy season and a drought period (veranico) in Summer.

\section{Materials and Methods}

The trial was carried out on a farm in Barra do Choça, Bahia State, Brazil (1441'15”S, 40²6'15”W, altitude $943 \mathrm{~m}$ ), from September 2016 to March 2017.

The site has a hot, temperate climate, with mean a annual temperature of $19.9^{\circ} \mathrm{C}$. Mean temperatures ranged from $26.8^{\circ} \mathrm{C}$ in the warmest month to $12.2^{\circ} \mathrm{C}$ in the coldest month (Cfb according to the Köppen and Geiger climate classification). Mean annual rainfall is $741 \mathrm{~mm}$, with the wettest months being December and January and the driest months being August and September. In this region, a prolonged drought occurs from February to April, the so-called veranico season (CONAB, 2016). During the trial, the daily mean temperature was $21.7^{\circ} \mathrm{C}$, and rainfall was $385.8 \mathrm{~mm}$ (Figure 1 ).

$$
\text { Month/day/ year }
$$

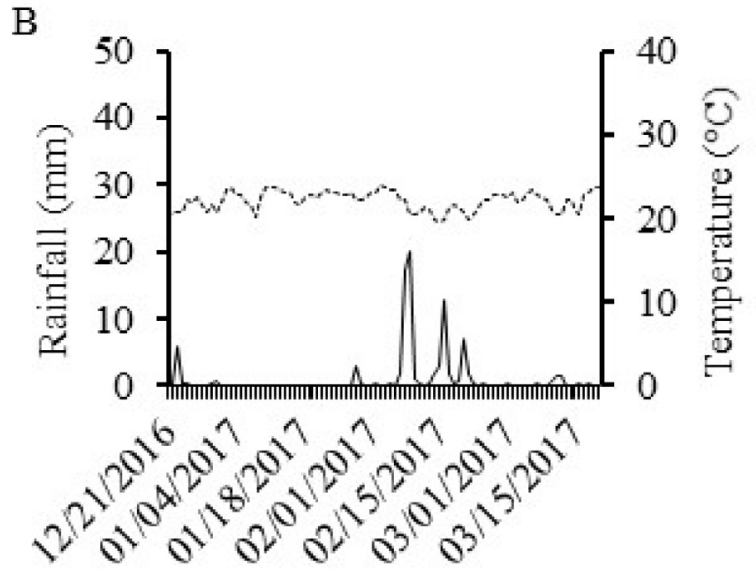

Month/ Day/ year

Figure 1 - Mean rainfall and temperature in the (A) rainy season 1 and (B) Summer season 2. 
Australian red cedar trees and Coffea arabica cv. Catutaí Vermelho were transplanted to the experimental area in April and October 2014, respectively. The trees were planted in two hedges, spaced $19.8 \times 3 \mathrm{~m}$ apart, in a northeast-southwest direction. Five coffee plant rows were grown between the hedges, spaced $3.3 \times 0.5 \mathrm{~m}$ apart. Treatments were defined by the distance (D) between the coffee plants and the first row of the Australian red cedar hedge $(3.3 \mathrm{~m}, \mathrm{~T} 1 ; 6.6 \mathrm{~m}, \mathrm{~T} 2 ; 9.9 \mathrm{~m}, \mathrm{~T} 3$; $13.2 \mathrm{~m}, \mathrm{~T} 4 ; 16.4 \mathrm{~m}, \mathrm{~T} 5)$, under rainfed conditions. Each experimental unit consisted of five coffee plants laid out in five blocks, totaling 25 plants per treatment.

Samples were collected from September to December 2016 (season 1, rainy season - S1) and from December 2016 to March 2017 (season 2, Summer veranico - S2).

For the morphological characterization of coffee plants, the following characteristics were measured: stem diameter (SD) $(0.03 \mathrm{~m}$ above ground), measured on orthotropic stems, using a digital caliper (model DC-6); lateral shoot number (LSN) and leaf number (LN), both by direct counting; and plant height $(\mathrm{H})$, from stem base to plant apex. Specific leaf area (SLA) was calculated with one leaf per experimental unit using a leaf area meter (model 3100, LI-COR, USA).

Leaf water potential $\left(\Psi_{w}\right)$ was determined according to the method described by Scholander et al. (1964). The first fully expanded leaf was collected from the stem located in the middle third of the plant, in the morning $\left(\Psi_{\text {wpd, }}\right.$ at 6:00 a.m.) and in the afternoon $\left(\Psi_{\text {wmd }}\right.$, at midday and 6:00 p.m.). The readings were taken using a pressure chamber (PMS 1000, PMS, Corvallis).

Relative water content (RWC) was estimated according to Čatský (1960). Ten leaf discs measuring $12.65 \mathrm{~mm}$ in diameter were collected using drills. The discs were weighed (fresh weight) and then placed in Petri dishes filled with deionized water. The Petri dishes were kept in a biological oxygen demand (BOD) incubator at a constant temperature of $25^{\circ} \mathrm{C}$ for $24 \mathrm{~h}$. After, the discs were weighed again (turgid weight) and oven-dried at $65^{\circ} \mathrm{C}$ to obtain the dry weight. RWC was calculated using Equation 1:

RWC $=[($ fresh weight - dry weight $) /($ turgid weight - dry weight) ${ }^{\star} 100$

In which:

values $=$ expressed as percentages.

Leaf greenness was determined using a portable chlorophyll content meter (SPAD 510, Minolta Camera Co., Osaka, Japan). The mean of three readings taken from each plant composing a plot was recorded.

Leaf temperature (LT) was measured on fully expanded leaves located in the middle third portion of the plant. Soil temperature (ST) was measured $50 \mathrm{~cm}$ above soil level. Both LT and ST were monitored at 6:00 a.m., 9:00 a.m., midday, 3:00 p.m., and 6:00 p.m. using a portable infrared thermometer (Multitemp, Radiant, China). Photosynthetic ac- tive radiation (PAR) was measured using a ceptometer (EMS-1, PP Systems, UK) at the same times of temperature readings, in both full sun ( $1.40 \mathrm{~m}$ above soil level) and above the plant canopy. PAR values were expressed as percentage.

For the bioassay of allelopathy, mature leaves were collected from the trees to prepare the extract by mixing $200 \mathrm{~g}$ of fresh leaf with $100 \mathrm{~mL}$ of heated distilled water. The resulting mixture was filtered. Aqueous solutions of polyethylene glycol (PEG) were prepared for concentrations $\left(\mathrm{Brix}^{\circ}\right)$ similar to those determined for the red cedar leaf extracts $(5,10,15$, and $20 \%$ and a control). Lettuce seeds (Lactuca sativa) were used as target species, following da Silva et al. (2019). This trial adopted a completely randomized design, with 4 replicates, each consisting of 25 lettuce seeds sown on germination test papers placed on Petri dishes, totaling 20 experimental units. The following characteristics were determined: germination speed (GS), germination percentage on the fourth day (G4), and response index (RI), following the procedure reported by Lungu et al. (2011).

Means were tested for homogeneity of variances (Cochran) and normality (Lilliefors). Afterward, a combined analysis of multiple experiments was performed using a 1:7 ratio constraint when grouping mean squared errors of single analyses. For the combined analysis, the mean square of each main factor was contrasted with the mean square of the interaction. Interactions were verified using the ratio of the mean square of the interaction to the mean square of the residual. When a significant difference was identified for the main factor season $(S)-$, the analysis of variance of the regression was used for the ratio of evaluated traits to the independent quantitative factor $\mathrm{D}$, with fitted models based on the coefficient of determination $\left(\mathrm{R}^{2} \geq\right.$ 50) and biological behavior. Data analyses were performed using the statistical software SAEG (Statistical and Genetic Analysis System, version 9.1).

\section{Results and Discussion}

Almost all environmental factors, including ST and PAR, as well as morphological and physiological responses of coffee plants, were affected by S. As for ST, LT, and RWC, higher values were found in S1 compared to S2. For most morphological characteristics, $\Psi_{w}$ and PAR measured in S2 were higher than those measured in S1 (Table 1).

Summer veranico reduced leaf RWC, although changes in $\Psi_{w}$ were less pronounced. According to Peloso et al. (2017), when leaves are subjected to water deficit, RWC decreases; thus, RWC is a good indicator of plant water status. In S1, higher LT and ST associated with increased vapor pressure deficit and decreased coffee leaf hydraulic conductance were related to partial stomatal opening and reduction in $\Psi_{\mathrm{w}}$ (Rodrigues, W.P. et al., 2016).

Stomatalopening and closing mechanisms are stronglylinked tolight fluctuations over the day. Therefore, in the early morning, regardless of shading conditions, stomata remain partially closed due to the low radiation intensity, thus restricting the stomatal function of attenuating LT. 
Table 1 - Morphophysiological characteristics of shade-grown Arabica coffee plants associated with toona trees (Toona ciliata M. Roem) cultivated in rainy Summer and Summer "veranico".

\begin{tabular}{|c|c|c|c|c|c|c|c|}
\hline \multirow{2}{*}{ Characteristic } & \multirow{2}{*}{ Time (h) } & \multirow{2}{*}{$\begin{array}{c}\text { Rainy } \\
\text { Summer }\end{array}$} & \multirow{2}{*}{$\begin{array}{l}\text { Summer } \\
\text { "veranico" }\end{array}$} & \multicolumn{4}{|c|}{ ANOVA $\operatorname{Pr}>\mathrm{F}$} \\
\hline & & & & Season (S) & Distance (D) & $S^{\star} D$ & CV (\%) \\
\hline $\mathrm{SD}(\mathrm{mm})$ & & $18.90 \mathrm{~B}$ & $23.40 \mathrm{~A}$ & * & * & ns & 12.8 \\
\hline LSN & & $32.05 \mathrm{~A}$ & $35.88 \mathrm{~A}$ & * & * & ns & 12.2 \\
\hline $\mathrm{H}(\mathrm{cm})$ & & $69.61 \mathrm{~B}$ & $97.40 \mathrm{~A}$ & $* *$ & $* *$ & ns & 7.2 \\
\hline SLA $\left(\mathrm{cm}^{2}\right)$ & & $23.55 \mathrm{~B}$ & $50.83 \mathrm{~A}$ & * & ns & ns & 16.1 \\
\hline $\mathrm{LN}$ & & $330.12 B$ & $484.12 \mathrm{~A}$ & ** & * & ns & 21.5 \\
\hline \multirow{3}{*}{$\Psi_{\mathrm{w}}(\mathrm{MPa})$} & 6 & $-0.94 \mathrm{~B}$ & $-0.40 \mathrm{~A}$ & * & ns & $* *$ & 27.9 \\
\hline & 12 & $-1.89 \mathrm{~B}$ & $-0.99 \mathrm{~A}$ & * & ns & * & 28.6 \\
\hline & 18 & $-1.29 \mathrm{~B}$ & $-0.31 \mathrm{~A}$ & ** & ns & ** & 26.7 \\
\hline RWC (\%) & & $80.80 \mathrm{~A}$ & $68.85 \mathrm{~B}$ & ** & ns & ns & 8.1 \\
\hline SPAD & & $67.06 \mathrm{~A}$ & $64.63 \mathrm{~A}$ & ns & ns & ns & 7.2 \\
\hline \multirow{5}{*}{$\mathrm{LT}\left({ }^{\circ} \mathrm{C}\right)$} & 6 & $17.95 \mathrm{~A}$ & $17.10 \mathrm{~A}$ & ns & ns & ** & 3.5 \\
\hline & 9 & $29.53 \mathrm{~A}$ & $23.43 \mathrm{~B}$ & $* *$ & ns & * & 9.4 \\
\hline & 12 & $43.05 \mathrm{~A}$ & $26.32 \mathrm{~B}$ & ** & ns & * & 11.6 \\
\hline & 15 & $33.66 \mathrm{~A}$ & $24.84 \mathrm{~B}$ & * & ns & $* *$ & 9.1 \\
\hline & 18 & $23.05 \mathrm{~A}$ & $20.36 \mathrm{~B}$ & $* *$ & ns & ns & 4.5 \\
\hline \multirow{5}{*}{$\mathrm{ST}\left({ }^{\circ} \mathrm{C}\right)$} & 6 & $19.90 \mathrm{~A}$ & $17.85 \mathrm{~B}$ & * & ns & $* *$ & 4.2 \\
\hline & 9 & $39.03 \mathrm{~A}$ & $28.67 \mathrm{~B}$ & * & ns & ** & 10.9 \\
\hline & 12 & $58.44 \mathrm{~A}$ & $39.39 \mathrm{~B}$ & $* *$ & ns & * & 12.5 \\
\hline & 15 & $39.11 \mathrm{~A}$ & $25.37 \mathrm{~B}$ & $* *$ & ns & $* *$ & 11.7 \\
\hline & 18 & $25.77 \mathrm{~A}$ & $20.36 \mathrm{~B}$ & ** & ns & ns & 3.8 \\
\hline \multirow{5}{*}{ PAR (\%) } & 6 & $59.88 \mathrm{~B}$ & $87.39 \mathrm{~A}$ & * & ns & ** & 27.2 \\
\hline & 9 & $82.03 \mathrm{~A}$ & $66.54 \mathrm{~B}$ & * & ns & ns & 46.0 \\
\hline & 12 & $90.18 \mathrm{~B}$ & $100.00 \mathrm{~A}$ & * & ns & $* *$ & 27.4 \\
\hline & 15 & $77.27 \mathrm{~A}$ & $90.34 \mathrm{~A}$ & ns & ns & $* *$ & 27.3 \\
\hline & 18 & $75.20 \mathrm{~B}$ & $99.33 \mathrm{~A}$ & * & ns & ns & 35.2 \\
\hline
\end{tabular}

${ }^{\star}$ Significance at $\mathrm{p} \leq 0.05 ;{ }^{*}$ Significance at $\mathrm{p} \leq 0.01$; ns: not significant. Means followed by different letters in the same line are significantly different ( $\mathrm{p}<0.05$, F-test); ANOVA: analysis of variance; CV: coefficient of variation; SD: shoot diameter; LSN: lateral shoot number; H: height; SLA: specific leaf area; LN: leaf number; $\psi_{\mathrm{w}}$ : predawn leaf water potential; RWC: relative water content; SPAD: soil plant analysis development index; LT: leaf temperature; ST: soil temperature; PAR: photosynthetic active radiation.

Coupled with this fact, the least difference in air temperature between S1 and S2 took place from 4:00 a.m. to 5:00 a.m., close to data collection at 6:00 a.m. (Figure 2).

Air temperature amplitude was lower between S1 and S2 compared with the interaction between $S$ and $D$. This difference was linked to the lack of effect of $S$ and D on LT in readings taken at 6:00 a.m. Trees are important for stabilizing the temperature within the agroforestry system, as they increase minimum mean temperatures and decrease maximum mean temperatures (Moreira et al., 2018). Nevertheless, air temperature and solar radiation showed higher spatial variability in shade-grown coffee fields, with modulations over the different seasons of the year (Petit-Aldana et al., 2017).
Soil plant analysis development (SPAD) readings were homogeneous (Table 1) due to a possible effect of the time of reading and to changes in leaf anatomy, thereby interfering with reading accuracy (Xiong et al., 2015; Padilla et al., 2019). Changes in light quality and intensity may affect the chloroplast position and, therefore, change real-time chlorophyll meter readings compared to chlorophyll content determined by destructive methods (Mamrutha et al., 2017). Although a close relationship between specific leaf area and chlorophyll meter readings has been reported and subsequently proposed as a procedure for plant breeding (Lisboa et al., 2019), no agreement has been reached on whether shade-induced morphological changes are always linked to increased leaf greenness. 
A

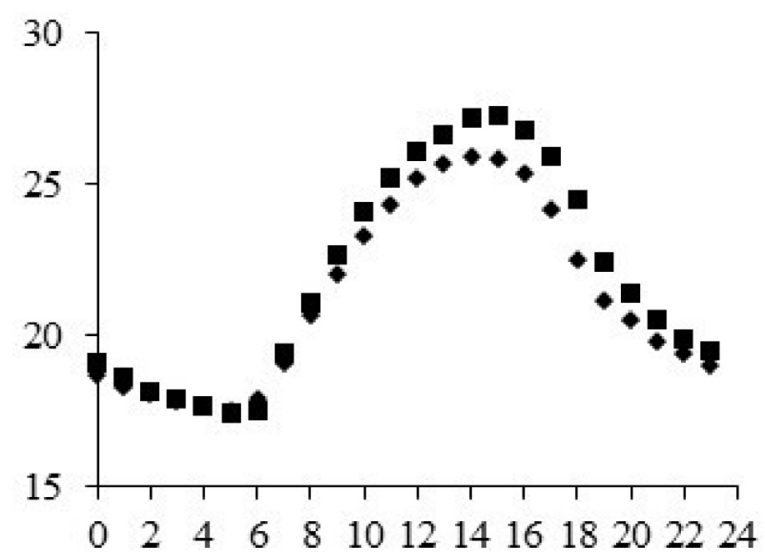

$\mathrm{C}$

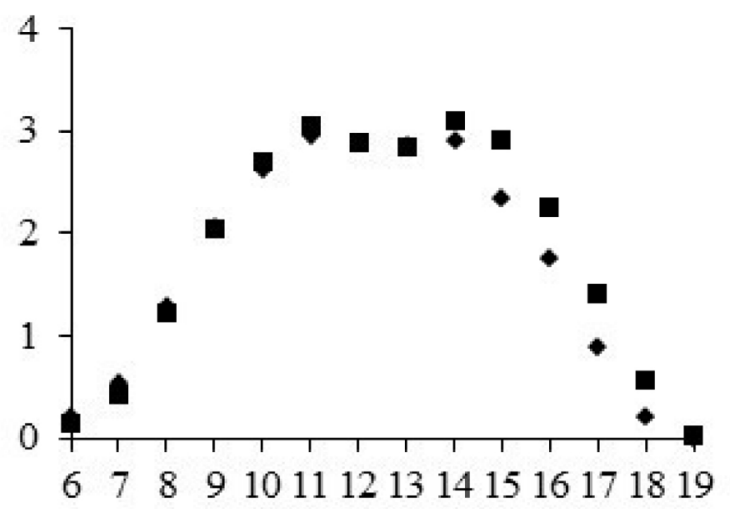

B

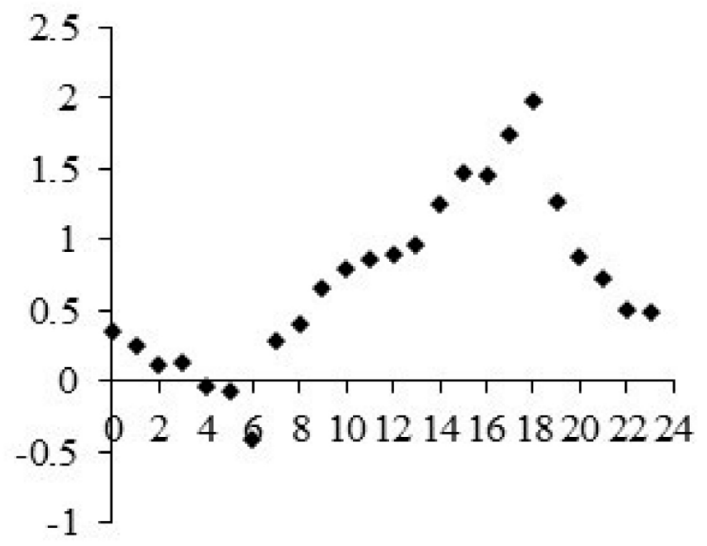

$\mathrm{D}$

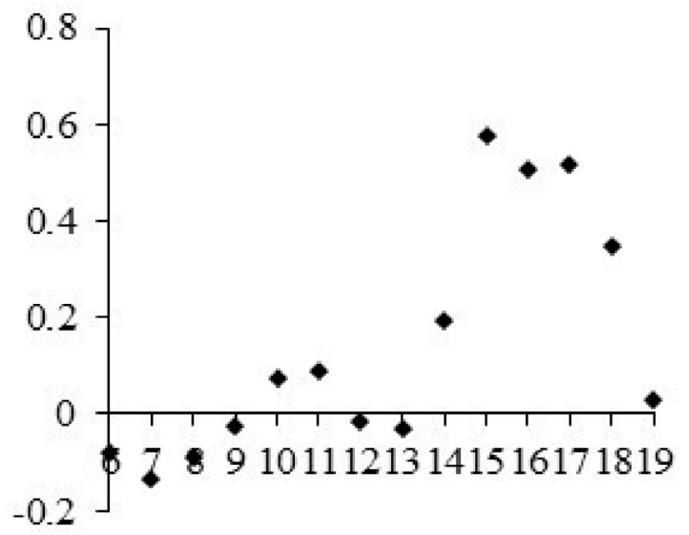

Figure 2 - (A) Fluctuations in daily temperature; (B) difference in thermal fluctuations over season $1-$ rainy season $-(\downarrow)$ and season 2 - Summer veranico - (-) in 2016/2017, measured every 60 minutes; (C) fluctuations in daily radiation; and (D) difference in radiation fluctuations between seasons 1 and 2 .

Growing trees among crop plants modifies the microclimate; however, factors such as tree arrangement, species, age, and management are determinants of these changes in tree-based systems.

As for the difference in PAR readings between S1 and S2, readings from S2 tended to be higher than those from S1 (Figure 2C). In field conditions, variations in relative PAR indices are common, and both arrangement and composition of the system are determinants of such fluctuations (Araújo et al., 2016).

The main factors $\mathrm{S}$ and $\mathrm{D}$ induced morphological changes in coffee plants. D had no impact on temperature, light, and water status; nonetheless, an interaction between $\mathrm{S}$ and $\mathrm{D}$ was observed for these characteristics (Table 1). These subtle interactions between factors altered environment characteristics but were not intense enough to induce morphological changes. Therefore, the integrated nature of morphological measurements differed from the specificity of measurements done for the environment and plant water status.

An interaction between D and S was identified for LT, ST, and PAR from 6:00 a.m. to 3:00 p.m., except at 9:00 a.m. (Table 1). The absence of interaction between $S$ and $D$ at 9:00 a.m. for PAR was associated with the radiation homogeneity at this time in both seasons (Figure 2D).

The relationship between morphological traits (SD, LSN, H, SLA, and LN) and D in S1 and S2 was fitted to a quadratic model that showed a less vigorous growth of coffee plants located closer to tree hedges (Figures $3 \mathrm{~A}, 3 \mathrm{~B}, 3 \mathrm{C}$, and 3D). Despite the similarity of the models for both 
seasons, the lower rainfall during S2 (veranico) intensified the shade effect on crop growth, thus resulting in more pronounced changes in growth traits (SD, LSN, H, and LN) for plants located farther from the hedge (Figures 3A, 3B and 3D). In S2, limited water and high temperatures (lower $\Psi_{w}$ and higher LT) in coffee plants located closer to the hedges resulted in lower leaf expansion and smaller SLA (Figure 3C).

Generally, decreases in SD, NL, and LSN are common plant responses to shading; however, decreases in $\mathrm{H}$ and SLA are not common in shade-grown coffee fields. Intense self-shading due to in- creased plant density coupled with the shade cast by the cedar hedges reduced light availability, reaching, at times, as low as $20 \%$ PAR. This scenario impaired growth and some photomorphogenesis processes. Although C. arabica is originally from forest understory, these plants are highly sensitive to limited light, and decreased vigor has been reported by many studies on increasing plant density in shaded areas.

Allelopathic interactions were also studied in bioassays carried out in the laboratory, showing that as the concentration of Australian red cedar extracts increases, lettuce seed germination decreases (Figures 4A, 4B, and 4C).
A

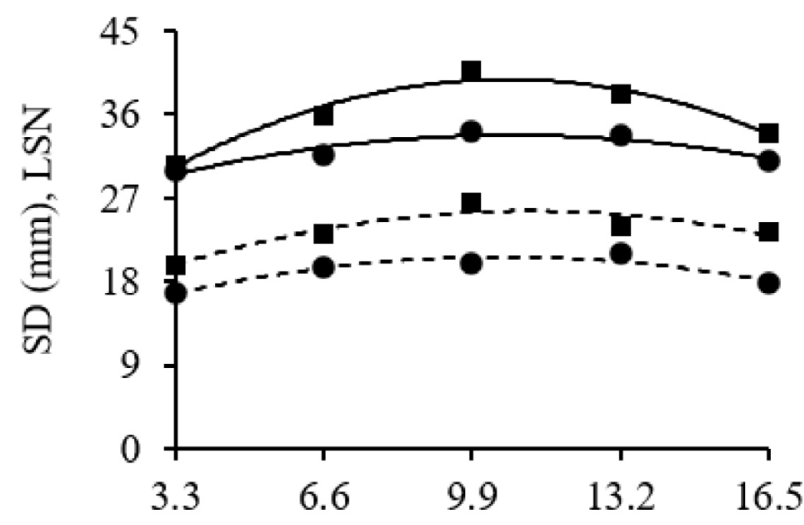

- $\hat{\mathrm{Y}}=12.245+1.586 \mathrm{x}-0.075 \mathrm{x}^{2} \quad \mathrm{R}^{2}=0.881$

$\hat{\mathrm{Y}}=13.952+2.081 \mathrm{x}-0.093 \mathrm{x}^{2} \quad \mathrm{R}^{2}=0.870$

- $\hat{\mathrm{Y}}=25.027+1.625 \mathrm{x}-0.076 \mathrm{x}^{2} \quad \mathrm{R}^{2}=0.904$

$\hat{\mathrm{Y}}=20.008+3.703 \mathrm{x}-0.173 \mathrm{x}^{2} \quad \mathrm{R}^{2}=0.965$

$\mathrm{C}$

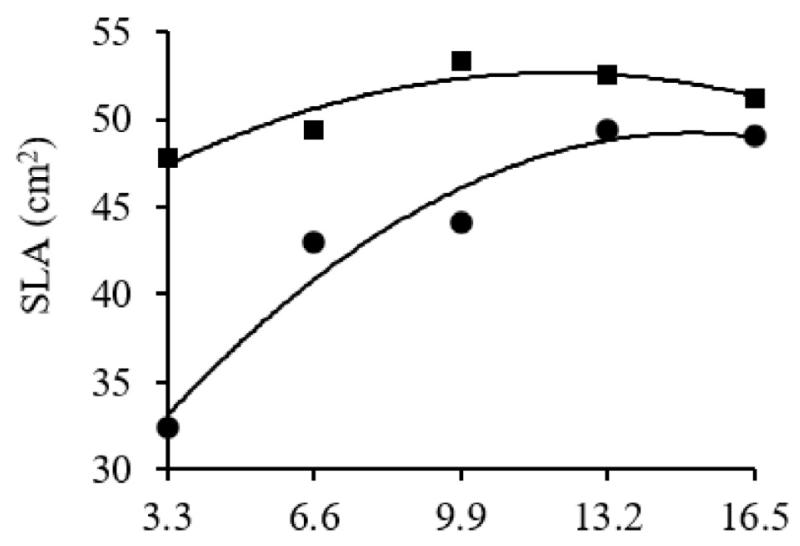

- $\hat{\mathrm{Y}}=22.790+3.495 \mathrm{x}-0.115 \mathrm{x}^{2} \quad \mathrm{R}^{2}=0.950$

$\hat{\mathrm{Y}}=42.673+1.651 \mathrm{x}-0.068 \mathrm{x}^{2} \quad \mathrm{R}^{2}=0.864$
B

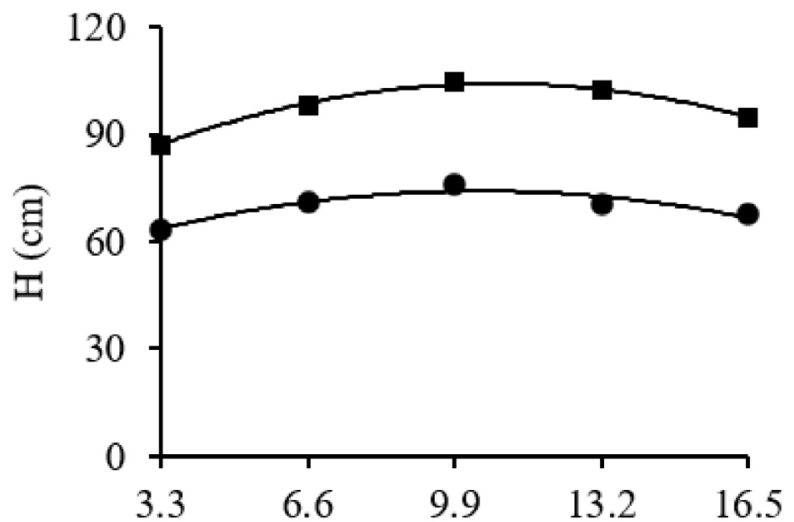

घ $\hat{\mathrm{Y}}=68.912+6.488 \mathrm{x}-0.298 \mathrm{x}^{2} \quad \mathrm{R}^{2}=0.996$

D

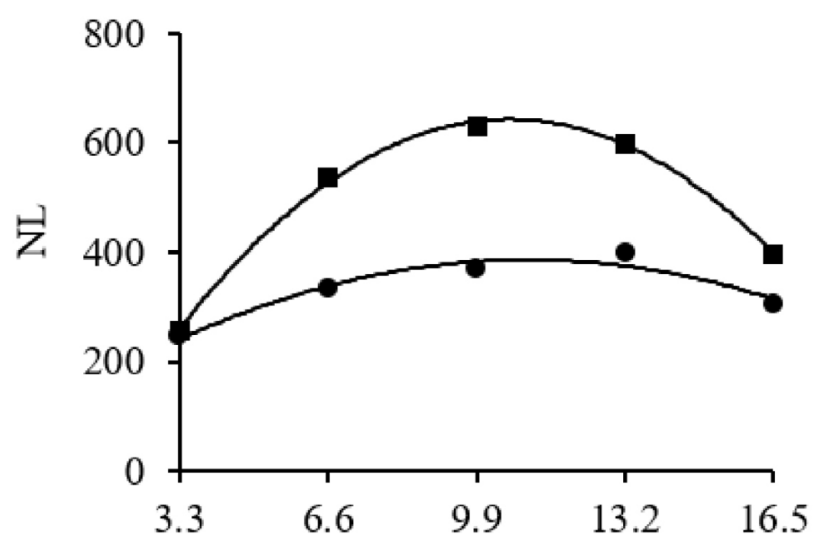

- $\hat{\mathrm{Y}}=90.360+53.552 \mathrm{x}-2.424 \mathrm{x}^{2} \quad \mathrm{R}^{2}=0.929$

- $\hat{\mathrm{Y}}=-161.4+151.360 \mathrm{x}-7.121 \mathrm{x}^{2} \quad \mathrm{R}^{2}=0.998$

Distance between coffee plants and Australian red cedar hedges (m)

Figure 3 - (A) Stem diameter (---), stem number ( - ); (B) height; (C) specific leaf area; and (D) leaf number determined in the rainy season $(\bullet)$ and Summer veranico (-) in coffee plants (Coffea arabica L.) shaded by Australian red cedar (Toona ciliata M. Roem). 
This effect on germination was associated only with allelopathic effects since the soluble solids concentration of the extracts did not have an osmotic effect on germination, as shown by tests with PEG.

Tree litter can release phytotoxic exudates into the soil, restricting germination (Rawat et al., 2017) and growth vigor of surrounding plants (Garima and Devi, 2017). Limonoids (De Leo et al., 2018; Zhang et al., 2019) and several phenolic compounds (Samaradivakara et al., 2016; Tandon and Sand, 2016) predominate among metabolites of Australian red cedar. Limonoids extracted from several species belonging to the family Meliaceae have phytotoxic properties that inhibit germination of many crops, such as maize, common bean, gourd, and lettuce (Parmar et al., 2019). According to Nebo et al. (2015), limonoids isolated from species of the family Meliaceae are important sources of allelochemicals with potential for agriculture.

A quadratic model relating leaf $\Psi_{w}$ to $D$ was defined for measurements done at 6:00 p.m. in S1 and S2. In S1, the highest $\Psi_{w}$ occurred mostly in coffee plants halfway between the Australian red cedar hedges (T3). The opposite trend was observed in S2 (Figures 5A and 5B).

Light intensity has a low impact on hydraulic responses of shadegrown coffee plants since C. arabica is original from shaded habitats where, from an evolutionary standpoint, the development of strategies regulating the plant hydraulics was limited (Miniussi et al., 2015). The presence of trees, however, modulates other environmental components that may contribute to the water status of coffee plants in a positive (presence of tree litter, reduced thermal amplitude, and limited soil evaporation) or negative way (superficial root development, competition between coffee plants and trees due to the reduced soil volume for the roots to explore).

In the S1 of this study, the lowest $\Psi_{w}$ and RWC in coffee plants nearer the red cedars was related to the decrease in soil volume exploration by coffee plant roots due to reduced crop vigor and the presence of trees (Figures 5A and 5C). Root volume associated with improvements in hydraulic conductance is an important factor determining water availability to plants. In S2, $\Psi_{w}$ had lower variation amplitude in response to D, with lower variations in LT and ST as well. The lowest leaf $\Psi_{w}$ observed in T3 (9.9 $\mathrm{m}$ from the hedges) compared to those nearer the trees was associated with the water deficit induced by the higher shoot vigor (greater number of leaves), hence, representing a greater sink.

In S2, the relationship between leaf greenness (SPAD) and D was fitted to a quadratic model, showing an increase in leaf greenness up to 14.33 m (Figure 5D), while Campa et al. (2017) reported an opposite trend. These authors verified that the shaded condition increased leaf greenness in coffee plants. Factors that may affect the relationship between SPAD readings and shading are time of reading and changes in specific and total leaf area (Xiong et al., 2015).

The relationship between RWC and D was fitted to similar models in S1 and S2 (Figure 5C). An upward trend in RWC was detected for coffee plants located halfway between hedges in S1, and a downward trend was identified for coffee plants located close to one of the hedges in S2. The occurrence of such differences was attributed to changes in the Earth's revolution around the Sun between S1 and S2.

Increases in evapotranspiration rates were associated with the reduction in RWC, which was indirectly affected by the higher LT (Figure 5C). A similar relationship was reported by Thioune et al. (2017).

For S1, LT, ST, and PAR responses to D, in nearly all times of reading, were fitted to a quadratic model (Figures 5E, 5F, 6A, 6B, 6C, and 6D). These models were characterized by lower values for coffee plants close to the hedges, except for measurements taken at 6:00 a.m. In the early morning, these values were higher in coffee plants located nearer the trees than in those farther away from the hedges. In S2, an upward linear trend in the relationship between LT and D was observed only at 3:00 p.m.
A

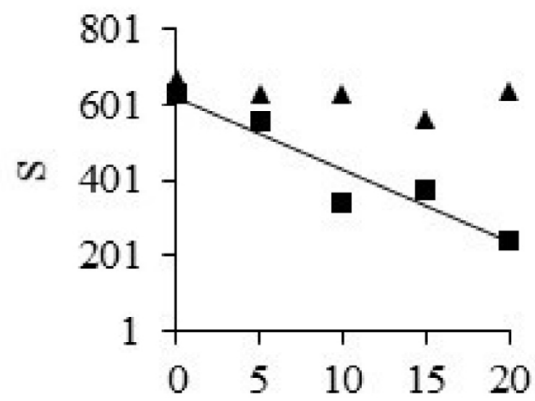

$$
\hat{\mathrm{Y}}=622.400-19.330 \mathrm{x} \quad \mathrm{r}^{2}=0.897
$$

B
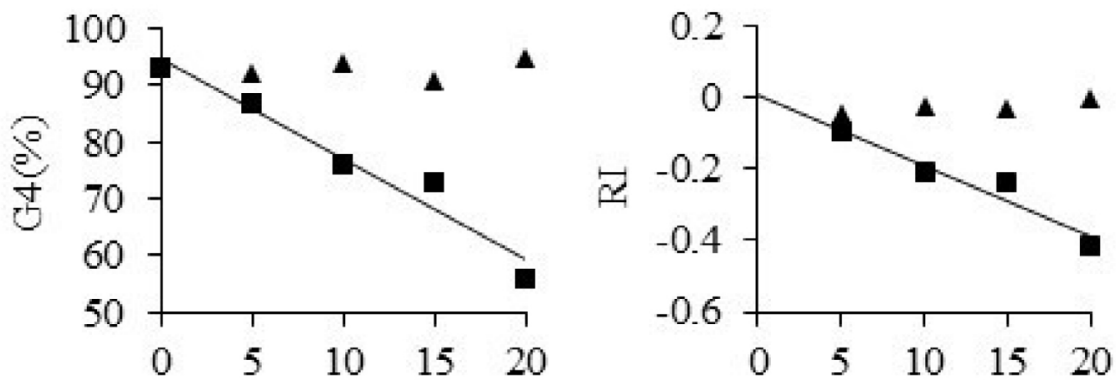

Australian red cedar leaf extract (\%)

Figure 4 - (A) Emergence speed index; (B) germination on the fourth day; and (C) response index in lettuce seeds (Lactuca sativa) subjected to Australian red cedar leaf extract $(\boldsymbol{\Delta})$ and polyethylene glycol solution $(-)$. 
A

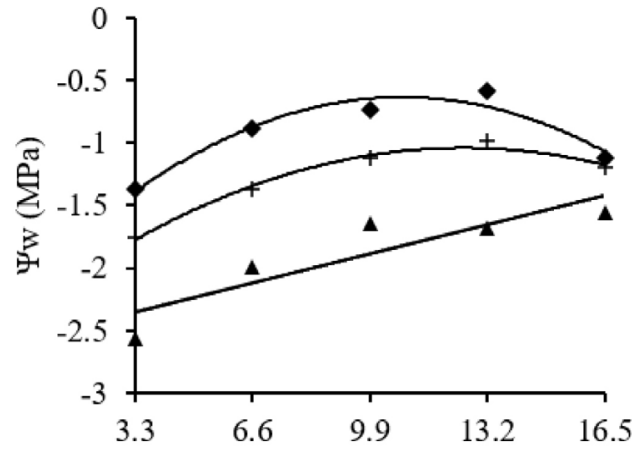

- $\hat{\mathrm{Y}}=-3.322+0.489 \mathrm{x}-0.022 \mathrm{x}^{2} \quad \mathrm{R}^{2}=0.965$

$\Delta \hat{\mathrm{Y}}=-2.587+0.071 \mathrm{x} \quad \mathrm{R}^{2}=0.789$

$+\hat{\mathrm{Y}}=-2.398+0.217 \mathrm{x}-0.009 \mathrm{x}^{2} \quad \mathrm{R}^{2}=0.986$

C

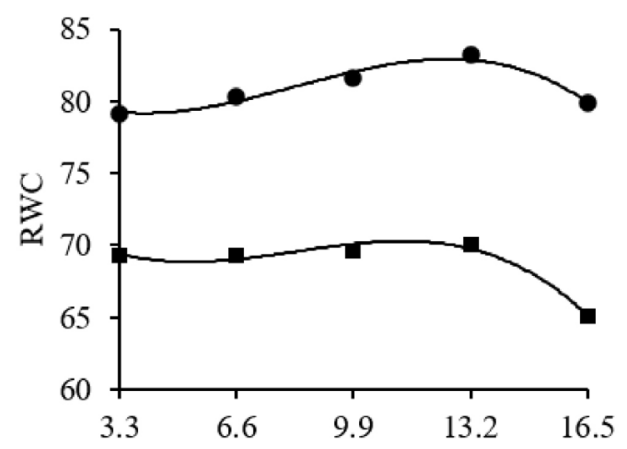

- $\hat{\mathrm{Y}}=61.282+1.314 \mathrm{x}-0.001 \mathrm{x}^{2}-0.004 \mathrm{x}^{3} \quad \mathrm{R}^{2}=0.950$

a $\hat{\mathrm{Y}}=82.340-1.779 \mathrm{x}+0.293 \mathrm{x}^{2}-0.012 \mathrm{x}^{3} \quad \mathrm{R}^{2}=0.957$

E

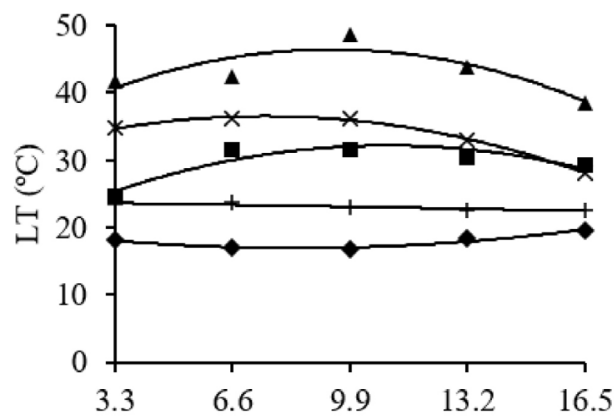

- $\hat{\mathrm{Y}}=19.901-0.7099 \mathrm{x}+0.0424 \mathrm{x}^{2} \quad \mathrm{R}^{2}=0.957$

- $\hat{\mathrm{Y}}=18.297+2.5344 \mathrm{x}-0.1157 \mathrm{x}^{2} \quad \mathrm{R}^{2}=0.849$

$\Delta \hat{\mathrm{Y}}=33.222+2.8217 \mathrm{x}-0.1508 \mathrm{x}^{2} \quad \mathrm{R}^{2}=0.738$

$\mathrm{X} \hat{\mathrm{Y}}=30.612+1.5741 \mathrm{x}-0.1047 \mathrm{x}^{2} \quad \mathrm{R}^{2}=0.997$

$+\hat{\mathrm{Y}}=23.861-0.074 \mathrm{x}-0.001 \mathrm{x}^{2} \quad \mathrm{R}^{2}=0.795$

Distance between coffee plants and Australian red cedar hedges (m)

F
B

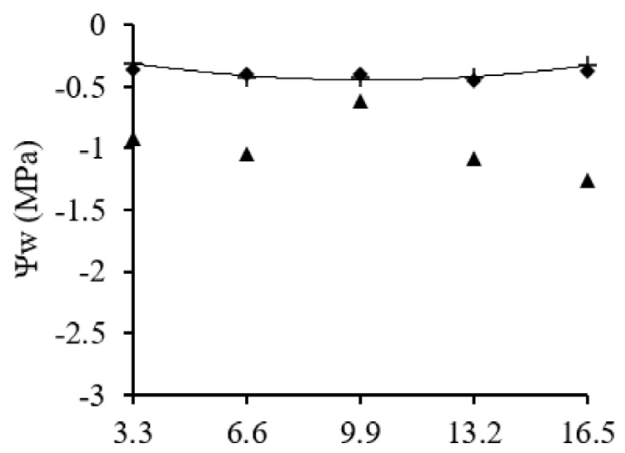

$+\hat{\mathrm{Y}}=-0.154-0.059 \mathrm{x}+0.003 \mathrm{x}^{2} \quad \mathrm{R}^{2}=0.933$

D

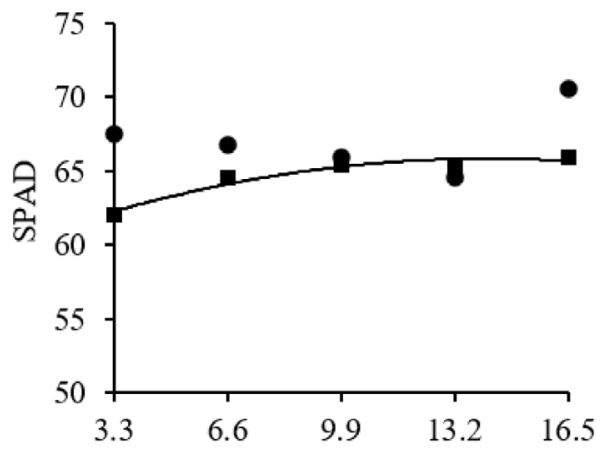

- $\hat{\mathrm{Y}}=59.755+0.860 \mathrm{x}-0.030 \mathrm{x}^{2} \quad \mathrm{R}^{2}=0.919$

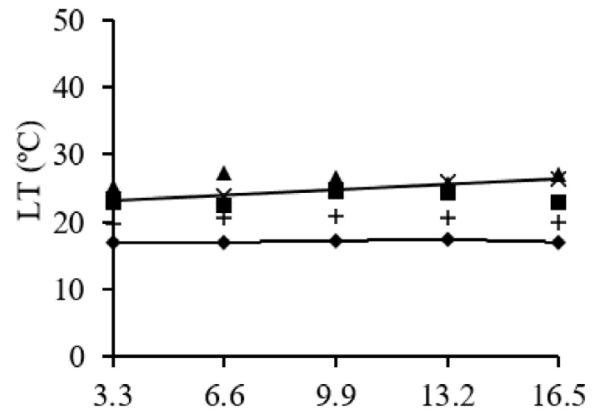

$\hat{\mathrm{Y}}=17.756-0.3586 \mathrm{x}+0.0485 \mathrm{x}^{2}-0.0018 \mathrm{x}^{3} \quad \mathrm{R}^{2}=1$

- $\hat{\mathrm{Y}}=22.447+0.2446 \mathrm{x} \quad \mathrm{R}^{2}=0.962$

Figure 5 - Water potential $(\Psi w)$ in $(A)$ the rainy season and $(B)$ Summer veranico measured at 6:00 a.m. ( ()$, 12: 00$ a.m. ( $\Delta$ ), and 6:00 p.m. (+); (C) relative water content (RWC) and (D) soil plant analysis development (SPAD) readings in the rainy season (•) and Summer veranico (•). Leaf temperature (LT) in (E) the rainy season and (F) Summer veranico measured at 06:00 a.m. ( $\bullet)$, 9:00 a.m. (•), 12:00 a.m. $(\Delta)$, 3:00 p.m. (x), and 6:00 p.m. (+) in coffee plants (Coffea arabica L.) shaded by Australian red cedar (Toona ciliata M. Roem). 
A

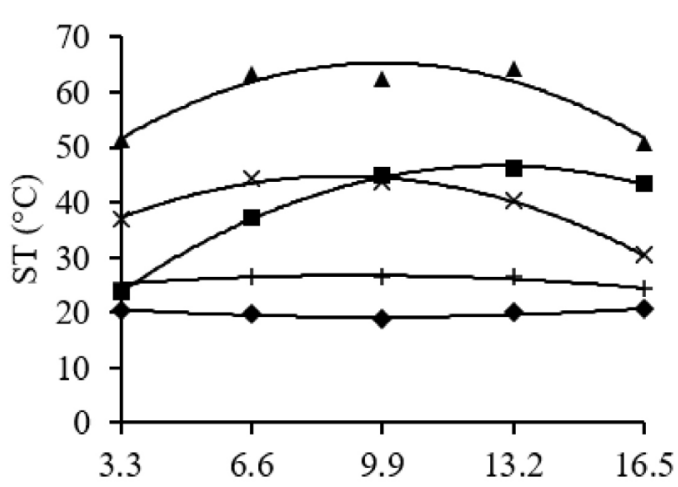

B

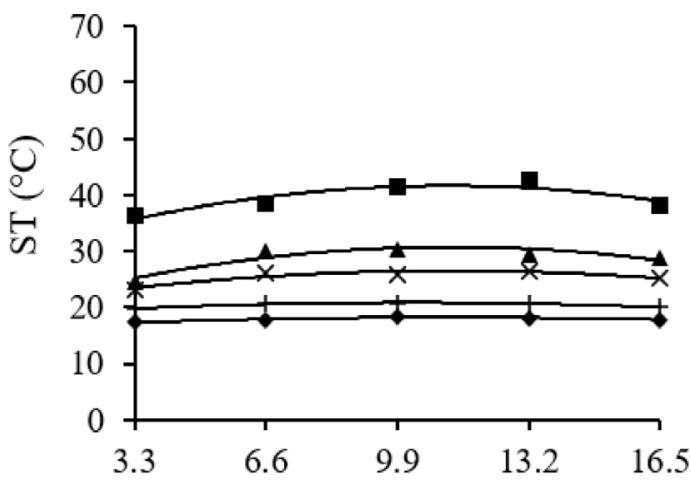

- $\hat{\mathrm{Y}}=22.316-0.6483 \mathrm{x}+0.0334 \mathrm{x}^{2} \quad \mathrm{R}^{2}=0.8126$

४ $\hat{Y}=16.348+0.3317 x-0.0148 x^{2} \quad R^{2}=0.9536$

- $\hat{\mathrm{Y}}=5.2648+6.4665 \mathrm{x}-0.2525 \mathrm{x}^{2}$

$\mathrm{R}^{2}=0.9982$

- $\hat{Y}=29.578+2.1592 x-0.0966 x^{2}$

$\mathrm{R}^{2}=0.8527$

$\Delta \hat{\mathrm{Y}}=34.314+6.2495 \mathrm{x}-0.3151 \mathrm{x}^{2}$

$\mathrm{R}^{2}=0.9086$

$\boldsymbol{\Delta} \hat{\mathrm{Y}}=19.629+1.9724 \mathrm{x}-0.0876 \mathrm{x}^{2}$

$\mathrm{R}^{2}=0.8685$

$\mathrm{x} \hat{\mathrm{Y}}=25.514+4.3491 \mathrm{x}-0.2458 \mathrm{x}^{2}$

$\mathrm{R}^{2}=0.9865$

$\mathrm{x} \hat{\mathrm{Y}}=20.381+1.0914 \mathrm{x}+0.0482 \mathrm{x}^{2}$

$\mathrm{R}^{2}=0.8722$

$+\hat{Y}=23.025+0.8065 x-0.0437 x^{2}$

$\mathrm{R}^{2}=0.9435$

$+\hat{Y}=18.502+0.4576 x-0.0223 x^{2}$

$\mathrm{R}^{2}=0.9572$

$\mathrm{C}$

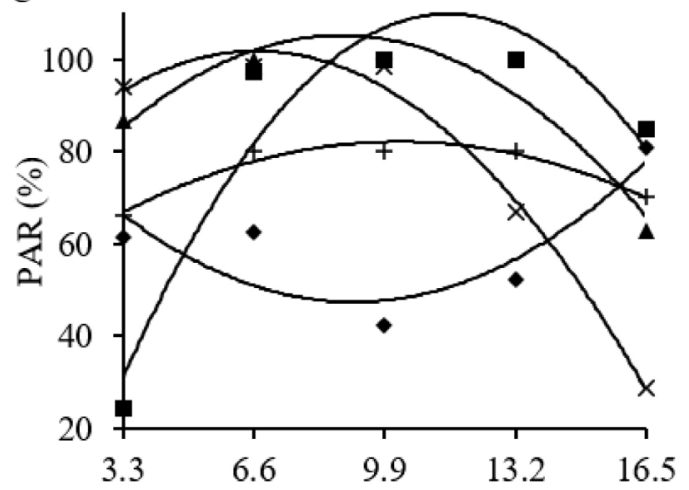

$\mathrm{D}$

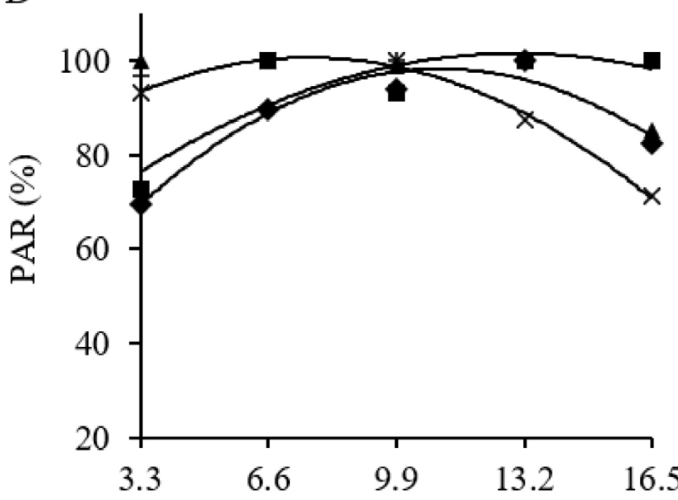

$\bullet \hat{\mathrm{Y}}=39.39+10.68 \mathrm{x}-0.484 \mathrm{x}^{2} \quad \mathrm{R}^{2}=0.941$

- $\hat{Y}=7.706+61.428 \mathrm{x}^{0.5}-8.704 \mathrm{x} \quad \mathrm{R}^{2}=0.811$

$x \hat{Y}=78.154+5.876 x-0.384 x^{2} \quad R^{2}=0.992$

- $\hat{\mathrm{Y}}=93.911-10.2101 \mathrm{x}+0.559 \mathrm{x}^{2} \quad \mathrm{R}^{2}=0.737$

- $\hat{Y}=-45.359+26.993 x-1.174 x^{2} \quad R^{2}=0.906$

$\Delta \hat{\mathrm{Y}}=53.747+11.669 \mathrm{x}-0.663 \mathrm{x}^{2} \quad \mathrm{R}^{2}=0.911$

$\mathrm{x} \hat{\mathrm{Y}}=67.950+10.136 \mathrm{x}-0.760 \mathrm{x}^{2} \quad \mathrm{R}^{2}=0.989$

$+\hat{\mathrm{Y}}=48.8+6.4762 \mathrm{x}-0.3148 \mathrm{x}^{2} \quad \mathrm{R}^{2}=0.946$

Distance between coffee plants and Australian red cedar hedges (m)

Figure 6 - Soil temperature (ST) in the (A) rainy season and (B) Summer veranico; photosynthetic active radiation (PAR) in the (C) rainy season and (D) Summer veranico measured at 6:00 a.m. (४), 9:00 a.m. (-), 12:00 a.m. ( $\Delta$ ), 3:00 p.m. (x), and 6:00 p.m. (+) in coffee plants (Coffea arabica) shaded by Australian red cedar (Toona ciliata M. Roem).

Light and temperature modulation by trees are important for coffee fields from an ecosystem point of view, especially in the prospect of climate change (Da Matta et al., 2018; Coltri et al., 2019).

The thermal attenuation caused by distances between trees and coffee plants was previously reported by Moreira et al. (2018). We underline the elevated plant and soil temperatures registered in Summer at midday, in agreement with Oliosi et al. (2016), who described a thermal index as high as $40^{\circ} \mathrm{C}$, at 12:00, in Summer and Autumn, in coffee plants maintained at $4.5 \mathrm{~m}$ of distance from cedar trees.

\section{Conclusions}

Environmental variations that occurred in the wet season and veranico in Summer affected the morphology, water relations, temperature, and light incidence in coffee plants associated with Australian red cedar hedges.

The distance from the hedge as a main effect has an impact on the morphology of coffee plants; however, it does not interfere with water relations, temperature, and PAR of coffee plants associated with red cedars. 
The allelopathic effect of Australian red cedars and the excessive self-shading are factors that reduce the growth of coffee plants located near the tree hedge.
The presence of trees attenuates fluctuations in temperature and PAR. Distance from the hedge and season are factors that determine to what extent these fluctuations are modulated.

\section{Contribution of authors:}

Pereira, L.F.: Conceptualization, Data curation, Formal analysis, Investigation, Methodology, Project administration, Visualization, Writing - original draft, Writing - review \& editing. Matsumoto, S.N.: Conceptualization, Data curation, Formal analysis, Funding acquisition, Investigation, Methodology, Project administration, Resources, Supervision, Visualization, Writing - original draft, Writing - review \& editing. Oliveira, U.S.: Data curation, Investigation, Project administration, Visualization, Writing - review \& editing. Viana, A.E.S.: Data curation, Formal analysis, Resources, Visualization, Writing - review \& editing. Teixeira, E.C.: Investigation, Project administration, Visualization, Writing - review \& editing.

\section{References}

Alves, V.; Goulart, F.F.; Jacobson, T.K.B.; Miranda Filho, R.J.; Ribas, C.E.D.C., 2016. Shade's benefit: coffee production under shade and full sun. Journal of Agricultural Science, v. 8, (11), 11-19. http://doi.org/10.5539/jas.v8n11p11

Araújo, A.V.; Partelli, F.L.; Oliosi, G.; Pezzopane, J.R.M., 2016. Microclimate, development and productivity of robusta coffee shaded by rubber trees and at full sun. Revista Ciência Agronômica, v. 47, (4), 700-709. https://doi. org/10.5935/1806-6690.20160084.

Bhardwaj, D.R.; Devi, Y.; Pala, N.A.; Sharma, U.; Kaushal, R., 2018. Influence of diameter class and field conditions on nutrient cycling under Toona ciliata M. Roem trees in north-western Himalaya. Environmental Processes, v. 5, (2), 427-440. https://doi.org/10.1007/s40710-018-0290-y.

Bote, A.D.; Ayalew, B.; Ocho, F.L.; Anten, N.P.; Vos, J., 2018. Analysis of coffee (Coffea arabica L.) performance in relation to radiation levels and rates of nitrogen supply I. Vegetative growth, production and distribution of biomass and radiation use efficiency. European Journal of Agronomy, v. 92, 115-122. https://doi.org/10.1016/j.eja.2017.10.007.

Campa, C.; Urban, L.; Mondolot, L.; Fabre, D.; Roques, S.; Lizzi, Y.; Arrrouf, J.; Doulbeau, S.; Breither, J.-C.; Letrez, C.; Toniutti, L.; Bertrand, B.; La Fisca, P.; Bidel, L. P. R.; Etienne, H., 2017. Juvenile coffee leaves acclimated to low light are unable to cope with a moderate light increase. Frontiers in Plant Science, v. 8, article 1126. https://doi.org/10.3389/fpls.2017.01126.

Čatský, J., 1960. Determination of water deficit in disks cut out from leaf blades. Biologia Plantarum, v. 2, (1), 76. https://doi.org/10.1007/BF02920701.

Coltri, P.P.; Pinto, H.S.; Gonçalves, R.R.V.; Zullo Junior, J.; Dubreuil, V., 2019. Low levels of shade and climate change adaptation of Arabica coffee in southeastern Brazil. Heliyon, v. 5, (2), e01263. https://doi.org/10.1016/j. heliyon.2019.e01263.

Da Matta, F.M.; Avila, R.T.; Cardoso, A.A.; Martins, S.C.; Ramalho, J.C., 2018. Physiological and agronomic performance of the coffee crop in the context of climate change and global warming: a review. Journal of Agricultural and Food Chemistry, v. 66, (21), 5264-5274. https://doi.org/10.1021/acs.jafc.7b04537.

Da Silva, M.C.; Araujo, E.C.G.; Silva, T.C.; Araújo, A.B.; Lins, T.R.S.; Leão, S.L.M.; Lima, T.V., 2019. Alelopatic effects of Tectona grandis LF in the germination and initial development of lettuce (Lactuca sativa L.). Journal of Agricultural Science, v. 11, (1), 382-387. https://doi.org/10.5539/jas.v11n1p382.

Da Silva Neto, F.J.; Bonfant, L.; Gazaffi, R; Fontanetti, A., 2019. Effects of shade trees spatial distribution and species on photosynthetic rate of coffee trees. Coffee Science, v. 14, (3), 326-337. https://doi.org/10.25186/cs.v14i3.
De Leo, M.; Milella, L.; Braca, A.; De Tommasi, N., 2018. Cedrela and Toona genera: a rich source of bioactive limonoids and triterpenoids. Phytochemistry Reviews, v. 17, (4), 751-783. https://doi.org/10.1007/s11101-018-9557-1.

Dias, K.G.D.L.; Guimarães, P.T.G.; Furtini Neto, A.E.; Silveira, H.R.O.D.; Lacerda, J.J.J., 2017. Effect of magnesium on gas exchange and photosynthetic efficiency of coffee plants grown under different light levels. Agriculture, v. 7, (10), 85. https://doi.org/10.3390/agriculture7100085.

Divakar, P.R., 2017. Phytopharmacology of Toona ciliata: a review. International Research Journal of Pharmacy, v. 8, (5), 30-35. https://doi. org/10.7897/2230-8407.08568.

Galetti, G.; Silva, J.M.S.; Piña-Rodrigues, F.C.M.; Piotrowiski, I., 2018. Análise multicriterial da estabilidade ecológica em três modelos de restauração florestal. Revista Brasileira de Ciências Ambientais (Online), (48), 142-157. https://doi.org/10.5327/Z2176-947820180301.

Garima; Devi, M., 2017. Allelopathy in agroforestry: A review. Journal of Pharmacognosy and Phytochemistry, v. 6, (3), 686-688.

Lisboa, L.A.M.; Lapaz, A.M.; Spósito, T.H.N.; Viana, R.S.; Figueiredo, P.A.M., 2019. Growth, development and foliar ultrastructural parameters of different eucalyptus genetic materials. Floresta, v. 49, (1), 21-30. https://doi.org/10.5380/ rf.v49i1.52527.

Lungu, L.; Popa, C.V.; Morris, J.; Savoiu, M., 2011. Evaluation of phytotoxic activity of Melia azedarach L. extracts on Lactuca sativa L. Romanian Biotechnological Letters, v. 16, (2), 6089-6095.

Mamrutha, H.M.; Sharma, D.; Kumar, K.S.; Venkatesh, K.; Tiwari, V.; Sharma, I., 2017. Influence of diurnal irradiance variation on chlorophyll values in wheat: A comparative study using different chlorophyll meters. National Academy Science Letters, v. 40, (3), 221-224. https://doi.org/10.1007/s40009-017-0544-7.

Meireles, I.E.S.; Matsumoto, S.N.; Reis, C.A.S.; Pereira, L.F.; Oliveira, U.S.; Barreto-Garcia, P.A.B.; Prado, T.R.; Ramos, P.A.S., 2019. Estimativa da biomassa de cafeeiros em sistemas agroflorestais sob manejo orgânico e convencional em diferentes arranjos. Revista Brasileira de Ciências Ambientais (Online), (53), 134-147. https://doi.org/10.5327/Z2176-947820190488.

Miniussi, M.; Terra, L. D.; Savi, T.; Pallavicini, A.; Nardini, A., 2015. Aquaporins in Coffea arabica L.: identification, expression, and impacts on plant water relations and hydraulics. Plant Physiology and Biochemistry, v. 95, 92-102. https://doi.org/10.1016/j.plaphy.2015.07.024.

Moreira, S.L.; Pires, C.V.; Marcatti, G.E.; Santos, R.H.; Imbuzeiro, H.M.; Fernandes, R.B., 2018. Intercropping of coffee with the palm tree, macauba, 
can mitigate climate change effects. Agricultural and Forest Meteorology, v. 256-257, 379-390. https://doi.org/10.1016/j.agrformet.2018.03.026.

National Supply Company (CONAB). 2016. Follow-up of the Brazilian Crop: coffee. Public survey of coffee crop of 2016. CONAB (Accessed September 20, 2017) at: https://www.conab.gov.br/info-agro/safras/cafe/boletim-da-safra-decafe? start $=10$.

Nebo, L.; Varela, R.M.; Molinillo, J.M.G.; Severino, V.G.P.; Sarria, A.L.F.; Cazala, C.M.; Fernandes, M.F.G.; Fernandes, J.B.; Macías, F.A., 2015. Phytotoxicity of triterpenes and limonoids from the Rutaceae and Meliaceae. $5 \alpha, 6 \beta, 8 \alpha, 12 \alpha$-tetrahydro-28-norisotoonafolin-a potent phytotoxin from Toona ciliata. Natural Product Communications, v. 10, (1), 17-20. https://doi. org/10.1177/1934578X1501000107.

Oliosi, G.; Giles, J.A.D.; Rodrigues, W.P.; Ramalho, J.C.; Partelli, F.L., 2016. Microclimate and development of' Coffea canephora cv. Conilon under different shading levels promoted by Australian cedar ('Toona ciliata' M. Roem. var. Australis). Australian Journal of Crop Science, v. 10, (4), 528-538. https://doi.org/10.21475/ajcs.2016.10.04.p7295x.

Oliveira, L.F.R.; Santos, P.H.R.; Silva, L.G.; Correia, L.P.S.; LAFETÁ, B.O., 2019 Cultivo de meliáceas arbóreas no Brasil. Applied Research \& Agrotechnology, v. 12, (2), 139-151. http://doi.org/10.5935/PAeT.V12.N2.14.

Padilla, F.M.; Souza, R.; Peña-Fleitas, M.T.; Grasso, R.; Gallardo, M.; Thompson, R.B., 2019. Influence of time of day on measurement with chlorophyll meters and canopy reflectance sensors of different crop N status. Precision Agriculture, v. 20, 1087-1106. https://doi.org/10.1007/s11119-019-09641-1.

Padovan, M.D.P.; Brook, R.M.; Barrios, M.; Cruz-Castillo, J.B.; VilchezMendoza, S.J.; Costa, A.N.; Rapidel, B., 2018. Waterloss by transpiration and soil evaporation in coffee shaded by Tabebuia rosea Bertol. and Simarouba glauca DC. compared to unshaded coffee in sub-optimal environmental conditions. Agricultural and Forest Meteorology, v. 248, 1-14. https://doi. org/10.1016/j.agrformet.2017.08.036.

Parmar, A.G.; Thakur, N.S.; Gunaga, R.P., 2019. Melia dubia Cav. leaf litter allelochemicals have ephemeral allelopathic proclivity. Agroforestry Systems, v. 93, 1347-1360. https://doi.org/10.1007/s10457-018-0243-5.

Peloso, A.D.F.; Tatagiba, S.D.; Reis, E.F.; Pezzopane, J.E.M.; Amaral, J.F.T., 2017. Photosynthetic limitations in leaves of arabic coffee promoted by the water deficit. Coffee Science, v. 12, (3), 389-399.

Petit-Aldana, J.; Lezama, C.P.; Rahman, M.M.; Arenas, O.R.; Infante-Cruz, A.; Basu, S.K., 2017. Coffee (Coffea arabica L.) agroforestry systems and solar radiation. In: Basu, S.K.; Zandi, P.; Chalaras, S.K. (Eds.), Environment at Crossroads: Challenges, Dynamics and Solutions. Haghshenass, Rasht, RAS, IRI, pp. 236-248.

Rawat, P.; Narkhede, S.S.; Rane, A.D.; Mhaiske, V.M.; Dalvi, V.V., 2017. Allelopathic effect of leaf leachates of solid bamboo Dendrocalamus stocksii (Munro.) on growth and yield of Eleusine coracana L. (Gaertn.). Indian Journal of Agroforestry, v. 19, (2), 79-82.
Ribeiro, A.F.F.; Matsumoto, S.N.; Pereira, L.F.; Oliveira, U.S.; Teixeira, E.C.; Ramos, P.A.S., 2019. Content of photosynthetic pigments and leaf gas exchanges of young coffee plants under light restriction and treated with paclobutrazol. Journal of Experimental Agriculture International, v. 32, (6), 1-13. https://doi.org/10.9734/jeai/2019/v32i630128.

Rodrigues, L.D.A.; Castro, E.M.; Pereira, F.J.; Maluleque, I.F.; Barbosa, J.P.R.A.D.; Rosado, S.D.S., 2016. Effects of paclobutrazol on leaf anatomy and gas exchange of Toona ciliata clones. Australian Forestry, v. 79, (4), 241-247. https://doi.org/10.1080/00049158.2016.1235476.

Rodrigues, W.P.; Martins, M.Q.; Fortunato, A.S.; Rodrigues, A.P.; Semedo, J.N.; Simões-Costa, M.C.; Pais, I.P.; Leitão, A.E.; Colwell, F.; Goulao, L.; Máguas, C.; Maia, R.; Partelli, F.L.; Campostrini, E.; Scotti-Campos, P.; Ribeiro-Barros, A.I.; Lidon, F.C.; Matta, F.M.; Ramalho, J.C., 2016. Longterm elevated air $\left[\mathrm{CO}_{2}\right]$ strengthens photosynthetic functioning and mitigates the impact of supra-optimal temperatures in tropical Coffea arabica and C. canephora species. Global Change Biology, v. 22, (1), 415-431. https:// doi.org/10.1111/gcb.13088.

Samaradivakara, S.P.; Samarasekera, R.; Handunnetti, S.M.; Weerasena, O.J., 2016. Cholinesterase, protease inhibitory and antioxidant capacities of Sri Lankan medicinal plants. Industrial Crops and Products, v. 83, 27-234. https:// doi.org/10.1016/j.indcrop.2015.12.047.

Scholander, P.F.; Hammel, H.T.; Hemmingsen, E.A.; Bradstreet, E.D., 1964. Hydrostatic pressure and osmotic potential in leaves of mangroves and some other plants. Proceedings of the National Academy of Sciences, v. 52, (1), 119125. https://doi.org/10.1073/pnas.52.1.119.

Schwerz, F.; Caron, B.O.; Nardino, M.; Elli, E.F.; Stolzle, J.R.; Carvalho, L.G.; Neto, D.D., 2020. Assessing yield, growth and climate traits in agroforestry systems in southern Brazil. Journal of Sustainable Forestry, 1746913. https:/// doi.org/10.1080/10549811.2020.1746913.

Tandon, S.; Sand, N.K., 2016. Qualitative analysis of phenolic constituents from leaves of some plants of family Meliaceae. International Journal of Medicinal Plants and Natural Products, v. 2, (1), 27-30. http://doi. org/10.20431/2454-7999.0201005.

Thioune, E.H.; McCarthy, J.; Gallagher, T.; Osborne, B., 2017. A humidity shock leads to rapid, temperature dependent changes in coffee leaf physiology and gene expression. Tree Physiology, v. 37, (3), 367-379. https://doi. org/10.1093/treephys/tpw129.

Xiong, D.; Chen, J.; Yu, T.; Gao, W.; Ling, X.; Li, Y.; Peng, S.; Huang, J., 2015. SPAD-based leaf nitrogen estimation is impacted by environmental factors and crop leaf characteristics. Scientific Reports, v. 5, 13389. https://doi.org/10.1038/ srep13389.

Zhang, L.; Xia, J.; Yang, J.; Zhu, L.; Tanga, D.; Ma, J.; Zhao, Y.; Zenga, X.; Qiu, M., 2019. Toona micronoids A-D, four new B-seco-limonoids from Toona microcarpa. Phytochemistry Letters, v. 31, 225-22819. 